\title{
PUBLIC POLICY REGARDING FOREST LANDS IN CANADA ${ }^{1}$ BY MURRAY B. MORISON2
}

\section{CHANGING ECONOMIC INFLUENCES}

In these days when we are inclined to boast of the great advancements made in science, industrial development and prosperity in general, I sometimes wonder-are we doing a better job in our development of forest policy than the Ancients, whose land use policy, we all know, was supremely inadequate. Were they more imprudent than we, or are we foolish in our belief that we can and will proceed along the path of conservation? Shall we prevent deterioration, even disintegration of our civilization or shall we follow in the footsteps of those who at one time could boast of a fertile Holy Land or a green forested Central Sahara?

Having regard to these questions, I see a greater need of widespread public education with special emphasis on fundamental points of policy for our forest patrimony. It is deserving of more widespread attention than that to be expected from the exploiter whose objectives are primarly economic and only mildly related to the principle of the greatest good to the greatest number of people. As Major-General Howard Kennedy put it, in his report of the Ontario Royal Commission on Forestry, "An enlightened public on guard against unwise exploitation of its forest resources is the influence most likely to assure the perpetuation of its forest resources for future generations".

Dr. Fernow in his History of Forestry refers to forestry as "an art born of necessity as opposed to arts of convenience and of pleasure. Only when a reduction in the natural supplies of forest products, under the demands of civilization, necessitates a husbanding of supplies or the application of art or skill or knowledge in securing reproduction, or when unfavourable influence of soil or climate induced by forest destruction, make themselves felt, does the art of forestry make its appearance." And it might be added that the art of forestry on public land is generally not voluntary, and it is not applied until a regulatory forest policy is enacted through legislation.

Mr. T. Francois, in his very good treatise on Forest Policy, Law and Administration has this to say about the relation of economic conditions to public policy.

"As matters stand today, there is frequently no relation between the importance of forests in the economic and social welfare of a country and the state of development of its forest law."

As a forester, looking upon this statement I must agree with Mr. Francois and also admit that it applies in some measure to Canada, both in its federal and its provincial aspects. It is most difficult in a land like ours for provincial forest policy to transcend the boundaries of industrial expediency which is generally clothed in "economic garb", while the federal authority seems to have great diffidence towards accepting the responsibilities that rest within its scope, on the national level.

The factors that hinder advanced forest legislation in Canada are un-

1 Presented at the joint annual meeting of the Canadian Institute of Forestry and Society of American Foresters in Montreal, November, 1952.

2 Division of Timber Management, Ontario Department of Lands and Forests, Toronto. 
doubtedly mainly economic, but must we allow it to remain that way to the bitter end? Can we not establish other factors of more lasting quality to influence our handling of forest lands? We need public recognition of their everlasting importance.

The forst lands of Canada are vast. Our forests support "Canada's Leading Industry" the pulp and paper industry. In this regard, Mr. Vernon Johnson, Vice-President and General-Manager of the Canadian International Paper Company, in an address before the International Circulation Manager's Association at Murray Bay, Quebec, June 13th, 1950, said: "Canada's woodland area is one of the world's greatest productive forests. About one-third of Canada is covered by forests- $1,220,000$ square miles. More than 700,000 square miles of forest lands are capable of producing continuous timber crops. About 473,000 square miles of this area are now classified as economically, financially and geographically accessible." And to give some idea of the demand for wood he pointed out that the newsprint industry alone operates 137 newsprint machines in 37 mills, producing 17,000 tons of newsprint every working day.

The gross value of production of the Canadian pulp and paper industry in 1949, with reports from 123 mills, amounted to $\$ 836,000,000$. In 1950 it increased over $14 \%$ to $\$ 954,000,000$. The rival sawmill industry for the year 1949 came sixth in the list of ten top industries, with a gross value of production of $\$ 396,000,000$. this from 7,460 mills.

\section{SOME OF THE OTHER FACTORS}

Land Tenure as a Factor

Unlike our neighbors to the south of us, we have retained most forest lands under public ownership. Hence, public policy is largely concerned with the management of state owned lands, generally known and referred to as Crown lands.

The accessible forest lands of Canada are reported to be classed by tenure as follows:

Crown Lands unalienated $43 \%$ or 203,000 sq. miles

Crown Lands under timber license $36 \%$ or 170,000 sq. miles Private land $21 \%$ or 100,000 sq. miles

Total

473,000 sq. miles

Changing economic conditions and other factors have played their part more towards changing the methods of licensing of cutting rights, the measurement of timber, the mode of collecting Crown charges and regulating the utilization, rather than changing the deeply seated concept of public ownership which has been alnost universal in this country. In the province of New Brunswick in 1870, the Surveyor General of the day suggested the sale of timber lands outright to the lumbermen, but the proposal got no further. The new Surveyor-General of 1871 was not in favour of such action and the matter was dropped. Even earlier, in 1854, as reported in A History of Crown Timber Regulations a select committee of the Parliament of Canada (consisting, at that time, of the United Provinces of Upper and Lower Canada which 
are now Ontario and Quebec) heard testimony from Mr. Jonathan R. White of the State of Michigan in support of the American system of land disposal with particular reference to forest lands, but Canadian Lumbermen and Crown Lands officials were against such a system here and expressed the view that "the exposition of the methods pursued in the United States rendered it abundantly evident that whatever defects might exist in the Canadian system it was much superior to that of the United States in the matter of preventing the monopoly of natural resources by comparatively few individuals and securing to the public treasury returns in some measure proportionate to the value of the privileges granted."

It seems to me that public ownership will continue despite the favourable results forecast by some of our contemporaries whose arguments support the early American system of private ownership of the forest and lean heavily upon this system as a "cure-all" for the forest management problems in Canada. An insufficiency of (1) local markets, (2) industrial research in utilization (3) transportation and (4) a sound inventory and appraisal of the forest and its potentialities upon which to base management, are factors of far greater importance. There would seem to be more reason to fear the business cycle and its many unpredictable ups and downs, than the risk of a public policy change regarding tenure which would be detrimental to the future of the forest industry, which is so important in the economy of this country.

Under the early French Regime of the Seventeenth Century, timber resources were regarded as of comparatively little commercial importance. The system of land disposal by the Crown into Seignories copied the old feudal system and the forests were treated merely as incidental. "Large areas were allotted to Seigniors, who were the only class to hold their titles directly from the Crown," and received their grants on the express condition of subdividing them among tenants or consitaires." Oak timber on the grants however was reserved for the purpose of naval construction although no Crown domain was reserved for this purpose or for other timber operations.

Under the British occupation in the middle of the Eighteenth Century, not only was pine reserved in the deeds, but early instructions were given for the reservation of large areas of forest for the erection of fortifications, barracks for military and naval services and particularly for the growth and production of naval timber. Instructions were later given that no grant be made on any lands on which there is any considerable growth of white pines fit for masting for our Royal Navy.

Naval contracts were the first form of licence issued for timber production from Crown lands and the contractors took advantage of this privilege to do a general business in supplying British markets. The concern of the British for a supply of naval and military timber seems to have been the forerunner of the present system of administering Crown forest lands in Canada.

As the timber trade with Britain expanded during the early Nineteenth Century, legislation was designed to assist in orderly sales to provide a flow of revenue to the Crown, and practically no thought was given to conservation either in the timber licensing system or in the prevailing system of granting large areas of wild land. 
Established Industry as a Factor.

It is not always easy to separate and designate the factors influencing public policy when changes are made, but in certain instances deductions may be nearly correct. To illustrate this point, I can refer back to 1837 , when the legislature of New Brunswick passed the Civil List Act during its first session after obtaining self government. Heretofore, Crown lands had been administered by officers appointed by the Home Office in London. Section V of the Civil List Act referred to the disposal of grants, leases, etc., making it necessary for them to be disposed of, to the highest bidder at public auction. Notwithstanding this provision for competition, the Act immediately following was "An Act to Restrain the Provisions of Section V", and in part it made it lawful to grant licenses for cutting and hauling lumber and logs by private sale. Furthermore any licensee could obtain a renewal without competition simply by petition before his license expired.

It would seem from that piece of legislation that established industry had a definite influence on public policy and was amply protected by the above measure.

Also, in New Brunswick, two Acts were passed in 1844, with the effect of making the collection of Crown charges less difficult and expensive. The first of these provided for an export duty on all lumber shipped from the province and the second allowed the sale of licenses on an area basis rather than a stumpage basis. This meant that timber used locally would not bear any dues while the larger proportion of the cut, being exported, would be subject to the duty. Crown charges were simply collected in a lump sum at the time of sale and the additional export duty was collected by the Customs when shipped. The cost of scaling which had been paid for by the operator would be reduced as no bush scale was required by the Crown, the operator would not have to complete payment for timber until it was leaving his hands, and there was probably no supervision of operations by the Crown.

This same type of legislation was recommended by $\mathrm{Mr}$. W. W. Dawson, a leading lumberman of Bytown (Ottawa) when giving testimony before a Select Committee of the Legislative Assembly of the United Provinces of Canada (now Quebec and Ontario) on January 30th, 1849. In addition he proposed an annual ground rent charge in place of the currently required deposit of one-fourth of the dues on the quantity of timber required to be taken out at the time of issue of a license for a season's operations. Under the system then in vogue, the order to manufacture a certain quantity of timber per square mile under license had, on account of the depressed state of the lumber trade, been reduced in a period of two months in 1846 from 5,000 cubic feet to 500 cubic feet per mile.

Established industry has been a dominant factor in determining methods of measuring timber, the main product and revenue producer of forest lands. Most log rules in use have probably been sponsored by industry and in some cases retained many years after becoming obsolete in their most important function, that of measuring the average out-turn of sawn lumber from the kind of logs currently produced. On the other hand, industry has at times 
been subjected to unreasonable systems of measurement and from time to time exerted pressure to correct apparent inequalities.

As long as the forest industry, including its manufacturing components, continues to be "Canada's Leading Industry" it will, as it should, continue to exert a great influence on public policy on forest lands in Canada. It will be a sorry day if this industry becomes so insignificant as to carry only a small voice in such matters but as I indicated earlier its influence should be tempered by an enlightened public opinion as expressed in up to date legislation.

New Industry as a Factor

New industry has an effect on resources management such as forestry, mining or fishing, that very often adds a welcome impetus towards the advancement of the principle of conservation because in forestry for example, new industry often eases the pressure on overworked species of timber suitable for select products and directs a wider utilization of the natural forest.

The growth of the pulp and paper industry with its revival of woods operations in many parts of Eastern Canada, after the hey-day of the square timber and sawlog operators, has done much to bolster revenues, provide more protection and establish forest management on a firmer basis.

The pulp and paper industry however has not been confined to the reviving of operations on old limits, but has also been allowed to expand into and develop less accessible forests. In doing so, it has presented another problem-the recognition and separation of products other than pulpwood from among the areas being operated. Pressure from sawlog, cross-tie and other converters, as well as public concern for a continuing lumber supply, has influenced governments to demand from the pulp and paper industry a broader understanding of their responsibilities to the general economy of the country.

On the other hand, this industry whose stake in the country is tremendous, in its own interest, does not favour the use of its capital and labour to produce for other industries raw material that it can use itself.

It is not easy to enact a public policy in a matter of this kind, that will take care of the various interests equitably, and for the greatest good to the greatest number of people.

New industry in the form of enlargement in the number of pulp making processes, thus also enlarging the number of species that are economical to use, aids in the application of more advanced silviculture as extra values accrue to forest lands. The good influence is not always easily measured. In fact, sometimes new uses seem to start bad practices that have to be overcome. On the whole, however, any new use, in a country where there is an excess of marginally merchantable species, should play its part towards better management of forest lands.

Miscellaneous Other Factors

Leaders in forestry, great teachers, men of vision who can sort out major factors influencing forestry at a given time, men who foresee an opportunity and direct advancement in forestry, men who defend and hold the line in times of adversity, groups of men in associations such as those represented here today, 
teams in industry and government, all have played their part under changing economic conditions in formulating or influencing public policy.

If I were to name some of them, I am sure that a number at this conference today would be in the list.

Forest fires, particularly very large fires and insect epidemics, have brought to the fore the need of greater protection services. Large amounts have been expended on organization and equipment for protection, the branch of forest management which has been the first to receive public recognition. New developments in other branches of forest management will bring to light a still greater need of protection.

Fish and wildlife management which in recent years has become an integral part of many provincial Departments of Lands and Forests has also and will continue to influence policies on forest lands. Registered trap lines, fish and game counts, the establishment of game preserves and the closing of areas or lakes to hunting and fishing, are all factors of import to the policy on forest lands. Tourists and their demands for beauty of landscape, green forests, the reservation of wilderness areas and limiting of transportation improvements as well as logging in such areas require special attention in the application of public policy.

New agricultural settlements, mining expansion, the development of hydro electric power, and many other activities and phases of a country's civilization, all claim their share of influence on policy.

\section{Sustained Yield Policy}

The chain store system of self-serve, the time honored method of obtaining Crown timber has run its course. The customer can no longer look over a vast supply, make his choice freely, and then get his timber at bargain prices. Throughout Canada there has been a gradual closing of the door while inventories are being taken. As a result, a more modern type of timber license or agreement is superseding any of the older types. It is better packaged to preserve the forest in logical management units and to maintain a permanent forest industry.

In recent years provincial governments have legislated to provide for forestry on a sustained yield basis. The first definite steps to this end have been taken in completing inventories and plans for regulation of the cut. Prosperity I would say, has been a big factor in this development. On the other hand, scarcity the lack of new timber frontiers, cannot be overlooked, and I believe also that foresters themselves, are beginning to have influence in the making of public forest policy in Canada. In British Columbia they call these new licenses Management Licences. In Ontario there is no special name for them, but since 1943 new agreements have contained clauses requiring the preparation of management and operating plans. Since 1922, Quebec has required pulpwood licencees to prepare inventories and furnish management plans. New Brunswick has since 1933 required pulp and paper companies to furnish plans covering their holdings. Manitoba has also passed legislation this year to place forest management on its woodlands under license. Thus, by the provincial legislative action mentioned above and also by the Small Trees 
Act in Nova Scotia and the Trees Conservation Act in Ontario pertaining to private lands as well as by the Canada Forestry Act passed in 1949, we see the effect of changing economic conditions and other factors on public policy regarding forest lands in Canada.

\section{REFERENCES}

(1) BEDARD AVILA and F. BOUTIN- "Administration of Crown Timber Lands in Quebec"

(2) BRODIE, J. A. "Timber Management in Ontario"-The Canadian Geographical Journal, March 1951 .

(3) CAIN, W. C. "Forest Management in Ontario"-The Forestry Chronicle, March 1939.

(4) Canada, The Canada Forestry Act, 1943

(5) CAVERHILL, P. L. "The Development of Forest Policy in British Columbia"-Empire Forestry Journal, Vol. 4, No. 1, 1925.

(6) Dominion Bureau of Statistics-"The Pulp and Paper Industry 1949".

(7) Dominion Bureau of Statistics-"The Pulp and Paper Industry 1950".

(8) Dominion Bureau of Statistics-"The Lumber Industry", 1949

(9) Dominion Forest Service-“"Canada's Foreste", 1949.

(10) FERNOW, B. E.- "Economics of Forestry", Thomas Y. Crowell \& Co., New York.

(12) FRANCOIS, T. "T. "Forest Policy, Law and Administration". Food and Agricultural Organization of the United Nations, Washington-Rome, December 1950.

(13) GIBSON, J. M.-Report on the Operation of the Small Tree Act to the Committee on Forestry and National Resources Legislative Assembly, Province of New Brunswick, 1952.

(14) GUTHRIE, JOHN A. "The Economics of Pulp and Paper" The State college of "Washington Press, Puliman, Washington.

(15) HARRISON, J. D. B. "The Influence of Economics on Forest Policy" The Forestry Chronicle, March 1942

(16) JOHNSON, VERNON E. "A New Era of Forest Management", Canadian International Paper Company, Montreal, P.Q.

(17) KENNEDY, HOWARD, Conmissioner, Report of the Ontario Royal Commission on Forestry, 1947.

(18) MORISON, M. B.-Forests of New Brunswick, Bulletin 91, Dominion Forest Service, 1938.

(19) MORISON, M. B.-The Evolution of Forest Policy in New Brunswick, Unpublished Manuscript and notes, 1936 .

(20) MULHOLLAND, F. D.- "Forest Policy-Ownership and Administration" Forestry Chronicle, March 1940.

(21) Nova Scotia, The Small Trees Act, 1942.

22) Ontario, "Report of the Minister of Lands and Mines", 1907.

(23) Ontario, "The Trees Conservation Act"

24) Prince Edward Island-"Act restricting cutting".

(25) SHARPE, J. F.- "Progress of Forestry in Ontario"-Proceedings Society of American Foresters' Meeting 1947. 